\title{
IL3RA wt Allele
}

National Cancer Institute

\section{Source}

National Cancer Institute. IL3RA wt Allele. NCI Thesaurus. Code C51365.

Human IL3RA wild-type allele is located in the vicinity of either Xp22.3 or Yp22.33 and is approximately $46 \mathrm{~kb}$ in length. This allele, which encodes interleukin-3 receptor subunit alpha protein, is involved in the regulation of tyrosine phosphorylation activity, and promotes hematopoietic cell proliferation and differentiation. 